\title{
Organizational justice mitigates adverse effects of perceived organizational politics on employee's turnover intentions at workplace
}

\author{
Muhammad Shafiq ${ }^{1}$, Noor Ullah Khan², Mansoor Bhatti ${ }^{3}$, Faisal Khan ${ }^{4 *}$ \\ ${ }^{1,2,3,4}$ Faculty of Management (FM), Universiti Teknologi Malaysia (UTM), Skudai Johor, Malaysia
}

* Corresponding author: faisalkhanutm@yahoo.com

\begin{abstract}
The objective of the present study was to investigate the relationship between organizational justice (procedural, interpersonal \& distributive), perceived organizational politics and turnover intentions of employees at a workplace. Furthermore the research study exposed that organizational justice mitigates negative effects of perceived organizational politics and can turnover intentions of employees. Sample size of 100 was selected via random probability sampling out of 320 employees from main head office and all branches of bank of Khyber Peshawar, KPK, Pakistan. The conclusion drawn from the research study is that organizational justice (procedural, interpersonal \& distributive) has significantly relation with perceived organizational politics and turnover intentions of employees at workplace. So managing organizational politics is a sensitive and critical issue. Therefore the study will facilitate human resource managers to cope with organizational politics and their negative outcomes. To manage the negative outcomes of organizational politics, the HR managers should realize the sensitivity of political environment inside the organization. The future studies may include all dimensions of justice and other job outcomes with a bigger sample size in order to increase the generalizability of results.
\end{abstract}

\section{ARTICLE INFORMATION}

Received: 25 March 2017

Revised: 25 March 2017

Accepted: 25 March 2017

DOI:

http://dx.doi.org//10.31580/jmi.v3i1.16

\section{Introduction}

Just assume a phenomenon that one of your coworker in other department has got an important and scarce resource from upper management in the organization. The coworker made access to this resource not because of scarcity but just because of connection with the upper management. So this is favoritism that is if some of the groups of employee's are getting more resources which actually they do not need as compared to other groups which are needy of such resources (Byrne, 2005). Research studies illustrate that individuals viewing the sort of behavior portrayed above generally view as politically charged behavior and they respond negatively ( Kacmar \& Ferris, 1991). For instance, those individuals who perceive politics inside organization show high level of tension and anxiety have strong tendency to quit (Cropanzano, 1997). Research Findings propose that politically charged and aggressive behavior possibly increase the cost of politics to the workers as well as organization (Kacmar \& Baron, 1999).

Organizational politics can be outlook as the deliberate attempt by individuals to advance and defend their own self-interest, even when possible at the cost of organization, and have no concern for the wellbeing of their fellows and organization. Political behavior can be distinguished as positive or negative but it depends on the context, the outcomes of negative political behavior have unfavorable effects on individuals as well as organization. Studies also suggest that politics are very important for organization to carry out usual business functions inside organization. So to minimize the negative effects of politics becomes very important (Andrews \& Kacmar, 2001).
Organizational justice is considered to be a promising tool for coping up and as well as mitigating these negative influences of organizational politics. Specifically justice measures and course of action expose honesty of management and make sure that employees are supporting their supervisors (Tyler \& Lind, 1992). In addition to this perceived justice minimizes the uncertainty inside organization atmosphere and provides an intellect of control to individuals. Those individuals who do perceive the mind-set of control inside organization atmosphere would prefers to take politics as opportunity and don't consider politics as threat. The perception of justice supposed to reduce the negative effects of politics (Ferris, 1989).

The previous study investigated the relationship between organizational justice including two dimensions i.e. procedural and interactional justice with politics, OCB and employees' turnover intentions (Byrne, 2005). But the current study will analyze the relationship between politics and justice by including third dimension of justice known as distributive justice, accordingly the relationship between organizational justice and politics with employee's turnover intentions yet to be explored in the context of Bank of Khyber Peshawar KPK Pakistan.

The prime objective of the current study was to analyze the relationship among organizational justice (interactional, procedural and distributive) and organizational politics with employee's turnover intentions in the context of Bank of Khyber Peshawar KPK Pakistan which never been explored. 


\section{Literature review}

\section{Organizational politics}

The politically charged behavior consists of two dimensions either positive or negative which are not element of the job and are not formally approved by the organization. We can see politics inside organization when the rules and regulation are not clear for existing behavior and decision making process. Politics can also make their place in case of scarcity of resources (Ferris \& Gilmore, 1995). Political perceptions are understood and just like when someone personally practiced some behaviors so we can say like this that the political perception depends upon perceiver's analysis of others behaviors. (Ferris \& colleagues,1995) have proposed that the amalgamation of perceived intention and cost of consequential politically charged behavior upon the perceiver which do affect either the perceived behavior is assumed positive or negative. Therefore the nature of political perception (positive or negative) to some extent depends upon perceiver perception (Andrews \& Kacmar, 2001).

Politics may be inspected in both dimensions (positive or negative). The austerity and occurrence of politics inside organization, the harshness of negative outcomes are the fruits of negative politics at individual as well as organizational level. (Kacmar, 1999) .The research illustrates that the majority of researchers have putted spotlight on negative outcomes of politics (Byrne, 2005).

So current research study would stay side by side with previous literature and will make a focus upon the perception of politically charged behavior (Byrne, 2005) all these perceptions which influence both employees as well as organization in a negative way (Gandz \& Murray, 1980). Particularly, how to minimize all these influences by means of organizational justice.

The finding shows that confirmation is questionable either perception of organizational politics is one-dimensional or multidimensional in context of measurement (Kacmar \& Baron, 1999). Few studies exposed that perception of organizational politics can be divided into so many different factors (e.g., Kacmar \& Ferris, Byrne, 2005), although some researcher proposed that division will not work out (e.g., Nye \& Witt, 1993). For instance, perception of organizational politics (pop) can be divided into two dimensions "general political behavior" (GPB) and "go along to get ahead" (GATGA; Kacmar \& Ferris, 1991). GPB means that explicit, political behaviors which assure the progress of individual benefit. Such behaviors are concern with obvious proceedings. (e.g., making rumors, making criticism on others) in order to promote their individual or groups self interest. The (GATGA) part of perception of organizational politics (pop) means exposing indirect behaviors to take personal benefit (Byrne, 2005).

\section{Adverse effects of organizational politics}

Organizational politics have association with unpleasant affects. Politics are creating stress in the organization atmosphere and also supporting the negative outcomes of stress. Politics has positive relationship with job anxiety (Cropanzano, 1997).

Finding also revealed that organizational politics shows significance in relationship with intent to leave (Ferris, 1993; Byrne, 2005). Further research exposed that intentions to leave have considerably related with actual turnover (Tett \& Meyer, 1993). Prior research exposed that organizational politics and "organizational citizenship behavior" (OCBs) have negative relationship (Randall, 1999). All those individual who posses negative perception about organizational politics make less efforts for the betterment of organization and as result it would influence the performance of employees (Randall\& colleagues, 1999).

\section{Organizational justice}

The "Rational model of authority" prescribes the procedure that how justice can minimizes the adverse effects of politics. Further the model proposed that justice procedures create good and positive understanding among workers and supervisor inside organization (Tyler \& Lind, 1992; Byrne, 2005). Research Findings exposed that organizational justice are positively related with organizational commitment, $\mathrm{OCB}$ and job satisfaction, while justice has negatively related with job stress turnover intention (Colquitt, 2001).

In nutshell the element of perceived of justice provides protection to the employees form politically charged behavior. The negative perception of individuals about politics can be minimized by boosting the fair conduct and measurers. Although findings proposed that politics has hold very critical stance for carrying out normal business operations (Pinto, 1997). So the presence of justice cannot abolish the political perception, so here it is assumed that justice should reduce the negative effects of organizational politics (Byrne, 2005).

\section{Dimensions of organizational justice}

Organizational justice can be categorized normally into three dimensions: interactional, procedural, distributive justice. But the recently the new dimension has been introduced that is informational justice. Distributive justice is concerned with the fairness of consequences (Deutsch, 1985). The prior studies proposed that distributive justice can predict the satisfaction of employees (Folger \& Konovsky, 1989). Procedural justice emphasizes on the fairness of procedure and processes that is used to be in making or implementing decisions and also distributing different outcomes (Thibaut \& Walker, 1975).

All those individuals who are taking procedural justice in positive way, they do perceive better sense of control inside organization atmosphere. Furthermore individuals are exposing less level of absenteeism, low level of intention to leave and show high level of performance and organizational commitment (Masterson, Goldman, $\&$ Taylor, 2000). Some studies proposed that Interactional justice is a part of procedural justice.

The fairness which is refers to the perception of interpersonal treatment of other individuals (e.g., respecting some with dignity and sensitivity respect) during the processes of making and implementing decisions. Furthermore it also emphasizes on the communicational and interpersonal sides of the processes (Bies \& Moag, 1986).

\section{The dimensions of organizational justice and politics}

The research findings proposed that the two dimensions of organizational justice (procedural \& distributive justice) have negative relationship with the organizational politics. However further findings exposed that procedural justice is more appropriate in the context of organizational politics because procedures constitute outcomes and also give the perception of control inside organization atmosphere (Andrews \& Kacmar, 2001).

The study proposed that the perception of interactional justice can possibly mitigate the negative effects of organizational politics, by making positive relationship with the supervisor. The findings also exposed that the perception of interactional justice shows negative relationship with employee's turnover intentions (Cohen-Charash \& Spector, 2001). Some research studies proposed that interactional justice is a part of procedural justice. But recent findings about justice exposed that both the components treated individually (Colquitt, 2001). Therefore prior studies are proposing that interactional justice is individually concern to manage negative outcomes of organizational politics. Furthermore current study would investigate the relationship of distributive justice with organizational politics. Prior research studies revealed that when employee feels that the environment inside organization is politically charged so then the employee exposed greater amount of anxiety and stress and less amount of general health. Likewise the long-term investment turns to be risky when the political environment inside organization becomes unpredictable. Then employees likely develop intent to leave and devote less effort for the growth and benefit of organization. On other hand supportive workplace is more predictable which provides opportunity to the employees to invest more inputs for the growth and betterment of organization (Cropanzano 1997).

\section{Theoretical framework}

The research study consisted of two theoretical frameworks proposed that the organizational justice and its components or dimensions 
(international, procedural and distributive) affect the organizational politics which in turns affects employee's turnover intentions. Furthermore the framework revealed that the three dimensions of justice (international, procedural and distributive) are independent, while organizational politics and turnover intentions are dependent variables in the study.
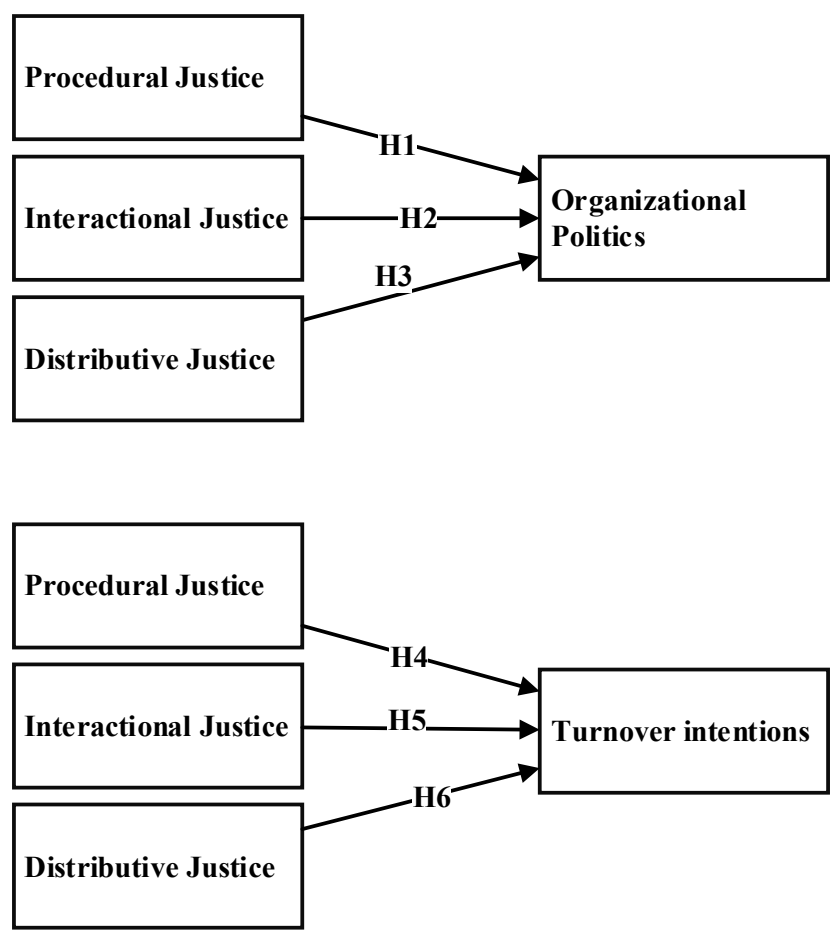

Fig.1. Theoritical Framwrok

\section{Proposed Hypotheses}

H1:Procedural justice has relationship with perceived organizational politics

H2:Interactional justice has relationship with perceived organizational politics

H3:Distributive justice has relationship with perceived organizational politics

H4:Procedural justice has relationship with employees' turnover intentions

H5:Interactional justice has relationship with employees' turnover intentions

H6:Distributive justice has relationship with employees' turnover intentions

\section{Methodology}

The primary data was collected from the main head office of Bank of Khyber and other branches which is located in the premises of Peshawar city. The selection of employees for data collection was made by keeping in view the nature of the data. So for this purpose employees of various hierarchal ranks were selected for data collection, because the variables of the research study aren't bound to any specific level inside organization.

The sample size of 100 was randomly selected out of 320 employees of different hierarchal levels from bank of Khyber. Forty questionnaires were distributed in head office and the remaining sixty questionnaires in different branches of bank of Khyber which are located in Peshawar city. Multiple regressions were used as statistical tool. The type of data is primary in nature because no prior research work has done in Pakistan particularly in banking sector. The data was gathered just only one time in order to test the research hypothesis so in this context the data nature is cross-sectional. The data analysis was done by using excel sheet and SPSS version -16.

\section{Survey instruments}

The existing standard questionnaires are used as survey instrument tool. The types of questionnaires are closed ended and designed in Likert scale. The questionnaire administered personally in order to motivate the respondents.

\section{Perception of organizational politics}

The perception of organizational politics was measured with 12-item scale developed by Kacmar and Ferris in 1991. Previous research showed this scale to be a good tool of psychometric properties (Kacmar and Carlson, 1997). A sample item was "Favoritism rather then merit determines who gets deed around here". All the questions were rated in five item scale ( $1=$ strongly disagree to $5=$ strongly $)$.

\section{Organizational justice dimensions}

The organizational justice three dimensions including (procedural, interactional \& distributive) were measured with multiple item scale developed by Colquitt (2001). Procedural justice was measured by 7 items, interactional justice measured via 4 -items and distributive justice measured with 4-items. A sample item was "Has (he/she) treated you with dignity". All the questions were rated in five item scale $(1=$ strongly disagree to $5=$ strongly $)$.

\section{Turnover intentions}

The Turnover intentions were measured with 3-item scale developed by Hom, Griffeth and Sellaro (1984). A sample item was "Do you intent to leave the organization in the next 12 months". All the questions were rated in five item scale $(1=$ strongly disagree to $5=$ strongly).

\section{Data analysis}

This research looks into the relationship of three dimensions of organizational justice (procedural justice, interactional justice and distributive justice) with politics and turnover intentions, Based on random sampling a sample of 100 numbers of employees from bank of Khyber. The instrument had items about organizational politics, three types of organizational justice (procedural, interactional and distributive justice) and turnover intentions. The analysis included, finding the descriptive statistics, and then causality was tested through multiple regression analysis.

Table 2.1: Correlations analysis

\begin{tabular}{lllllll}
\hline & & OP & TI & PJ & IJ & DJ \\
\hline OP & Pearson Correlation & 1 & $.418^{* *}$ & $-.672^{* *}-.477^{* *}$ & $-.254^{*}$ \\
& Sig. (2-tailed) & & .000 & .000 & .000 & .011 \\
& $\mathrm{~N}$ & 100 & 100 & 100 & 100 & 100 \\
TI & Pearson Correlation & $.418^{* *}$ & 1 & $-.237^{*}$ & -.142 & -.012 \\
& Sig. (2-tailed) & .000 & & .018 & .158 & .902 \\
& N & 100 & 100 & 100 & 100 & 100
\end{tabular}

${ }^{* *}$. Correlation is significant at the 0.01 level (2-tailed)

*. Correlation is significant at the 0.05 level (2-tailed)

OP=Organizational Politics, TI=Turnover Intentions, $\mathrm{PJ}=$ Procedural Justice, $\mathrm{IJ}=$ Interactional Justice, $\mathrm{DJ}=$ Distributive Justice

Hypothesis 1: The analysis supports the supposed hypothesis where there is a negative relationship among procedural justice and organizational politics. The value co-efficient of correlation $(\mathrm{r}=-.672)$. Hypothesis 2: The analysis table also shows supportive stance for hypothesis 2 that both interactional justice and organizational politics are negatively related with each other the value co-efficient of correlation is about $(\mathrm{r}=-.477)$. 
Hypothesis 3: The results are supporting the hypothesis there relationship between distributive justice and organizational politics is negative. The value co-efficient of correlation ( $\mathrm{r}=-.254)$.

Hypothesis 4: The data from the analysis table depicts that hypothesis supported the relationship among procedural justice and turnover intentions is negative. The value of correlation coefficient $(\mathrm{r}=-.237)$.

Hypothesis 5: The analysis table revealed that hypothesis supported the relationship between interactional justice and turnover intentions which is negative. The value of correlation coefficient is $(\mathrm{r}=-.142)$

Hypothesis 6: The analysis table suggests that hypothesis is not supported because the value of correlation coefficient is almost equal to zero, which shows there is no relationship existing between distributive justice and turnover intentions. The value of correlation coefficient is $(\mathrm{r}=-.012)$.

\section{Regression analysis}

The regression analysis tables expose the scores of co-efficient of determination, mean square, and the significance level among the study variables. The simple regression analysis shows the individual significance of all the three variables individually with organizational politics.

Table 1: Simple regression analysis of procedural justice and politics

\begin{tabular}{|c|c|c|c|c|c|}
\hline Model & $\begin{array}{l}\text { Sum } \\
\text { Squares }\end{array}$ & of Df & $\begin{array}{l}\text { Mean } \\
\text { Square }\end{array}$ & $F$ & Sig. \\
\hline 1 Regression & 15.323 & 1 & 15.323 & $\begin{array}{l}80.77 \\
3\end{array}$ & $.000 \mathrm{a}$ \\
\hline Residual & 18.590 & 98 & .190 & & \\
\hline Total & 33.913 & 99 & & & \\
\hline
\end{tabular}

a. Predictors: (Constant), procedural justice

b. Dependent Variable: organizational politics

Hypothesis 1 The simple linear regression analysis exposed that individually the procedural justice is significantly related with organizational politics. So the regression analysis is supporting the hypothesis because significance level is $\mathrm{F}(80.773)=80.77, \mathrm{p}<0.05)$ with an R2 of 0.446 means $46 \%$ organizational justice explained by procedural justice.

Table 2: Simple regression analysis of interactional justice and politics

\begin{tabular}{|c|c|c|c|c|c|}
\hline Model & $\begin{array}{l}\text { Sum } \\
\text { Squares }\end{array}$ & of Df & $\begin{array}{l}\text { Mean } \\
\text { Square }\end{array}$ & $\mathbf{F}$ & Sig. \\
\hline 1 Regression & 7.713 & 1 & 7.713 & $\begin{array}{l}28.84 \\
8\end{array}$ & $.000^{a}$ \\
\hline Residual & 26.200 & 98 & .267 & & \\
\hline Total & 33.913 & 99 & & & \\
\hline
\end{tabular}

a. Predictors: (Constant), interactional justice

b. Dependent Variable: organizational politics

Hypothesis 2 The regression analysis table also shows supportive stance for hypothesis 2 that interactional justice is significantly predicting the politics. There is significant level is $\mathrm{F}(28.848)=28.84$, $\mathrm{p}<0.05$ ) with an R2 of 0.227 ) means $28 \%$ organizational politics explained by the interactional justice.

Table 3: Simple regression analysis of distributive justice and politics

\begin{tabular}{|c|c|c|c|c|c|}
\hline Model & $\begin{array}{l}\text { Sum } \\
\text { Squares }\end{array}$ & of Df & $\begin{array}{l}\text { Mean } \\
\text { Square }\end{array}$ & $\mathbf{F}$ & Sig. \\
\hline 1 Regression & 2.195 & & 2.195 & 6.782 & $.011^{\mathrm{a}}$ \\
\hline Residual & 31.718 & 98 & .324 & & \\
\hline
\end{tabular}

Total $33.913 \quad 99$

a. Predictors: (Constant), distributive justice

b. Dependent Variable: organizational politics

Hypothesis 3 The regression results supported the hypothesis partially that the distributive justice is significantly predicting the organizational politics. The significance level is $\mathrm{F}(6.782)=6.00, \mathrm{p}<$ 0.05 ) with an R2 of .065) organizational politics explained by the distributive justice. The value of significance in table is .01 which is considered to be significant at $95 \%$ level of significance.

The multiple regression analysis shows the overall significance of all the three variables collectively with organizational politics.

The multiple regression analysis shows that the three dimensions of organizational justice (procedural, interactional and distributive justice) together significantly predicted the organizational politics. The level of significance $F(27.547)=27.55, p<0.05)$ with an R2 of .463) means almost $46 \%$ organizational politics explained by the all the dimensions of organizational justice collectively.

The simple linear regression analysis shows the individual significance of all the three dimensions of organizational justice individually with turnover intentions.

Table 4: Multiple regression of justice and politics analysis summary

\begin{tabular}{|c|c|c|c|}
\hline Model R & $\begin{array}{l}\mathbf{R} \\
\text { Square }\end{array}$ & $\begin{array}{l}\text { Adjusted } \\
\text { Square }\end{array}$ & $\begin{array}{l}\text { R Std. Error of the } \\
\text { Estimate }\end{array}$ \\
\hline $\begin{array}{l}.680 \\
a\end{array}$ & .463 & .446 & .43571 \\
\hline
\end{tabular}

a. Predictors: (Constant), distributive justice, interactional justice , procedural justice

Table 5: Multiple regression analysis of three dimensions of justice and politics

\begin{tabular}{llrlll}
\hline Model & $\begin{array}{l}\text { Sum } \\
\text { Squares }\end{array}$ & $\begin{array}{c}\text { of df } \\
\text { Mean } \\
\text { Square }\end{array}$ & F & Sig. \\
\hline 1 Regression & 15.688 & 3 & 5.229 & 27.54 & $.000^{\mathrm{a}}$ \\
& & & & 7 & \\
Residual & 18.225 & 96.190 & & \\
Total & 33.913 & \multicolumn{2}{c}{99} & &
\end{tabular}

a. Predictors: (Constant), distributive justice , interactional justice, procedural justice

b. Dependent Variable: organizational politics

Table 6: Simple regression analysis of procedural justice and turnover intentions

\begin{tabular}{|c|c|c|c|c|c|}
\hline Model & $\begin{array}{l}\text { Sum } \\
\text { Squares }\end{array}$ & of Df & $\begin{array}{l}\text { Mean } \\
\text { Square }\end{array}$ & $F$ & Sig. \\
\hline 1 Regression & 5.495 & 1 & 5.495 & 5.806 & $.018^{a}$ \\
\hline Residual & 92.743 & 98 & .946 & & \\
\hline Total & 98.238 & 99 & & & \\
\hline
\end{tabular}

a. Predictors: (Constant), procedural justice

b. Dependent Variable: turnover intentions

Hypothesis 4 The data from the simple linear regression analysis table depicts that hypothesis is supported the procedural justice is significantly related with turnover intentions. The level of significance $F(5.806)=5.80, p<0.05)$ with an $R 2$ of .056) explained by procedural justice. The value of significance is .018 which is significant at $95 \%$ level of significance.

Table 7: Simple regression analysis of interactional justice and turnover intentions

\begin{tabular}{llccc}
\hline Model & Sum & of Df $\begin{array}{l}\text { Mean } \\
\text { Square }\end{array}$ & F & Sig. \\
\hline
\end{tabular}




\begin{tabular}{|c|c|c|c|c|}
\hline Regressi & 1.987 & & 1.987 & $\begin{array}{l}2.02 \\
3\end{array}$ \\
\hline Residual & 96.251 & & .982 & \\
\hline Total & 98.238 & 99 & & \\
\hline
\end{tabular}

a. Predictors: (Constant), interactional justice

b. Dependent Variable: turnover intentions

Hypothesis 5 The simple linear regression analysis table revealed that hypothesis is not supported because the relationship between interactional justice and turnover intentions is insignificant. The level of significance is almost nil $\mathrm{F}(2.023)=2.02, \mathrm{p}<0.05)$ with an R2 of .020 ) means only $2 \%$ turnover intentions explained by interactional justice. The value of significance is .158 which is insignificant at $95 \%$ significance level.

Table 8: Simple regression analysis of distributive justice and turnover intentions

\begin{tabular}{|c|c|c|c|c|c|c|}
\hline \multicolumn{2}{|c|}{ Model } & \multirow{2}{*}{$\begin{array}{l}\begin{array}{l}\text { Sum } \\
\text { Squares }\end{array} \\
.015\end{array}$} & \multirow{2}{*}{$\begin{array}{c}\text { of Df } \\
1\end{array}$} & \multirow{2}{*}{$\begin{array}{l}\text { Mean } \\
\text { Square }\end{array}$} & \multirow{2}{*}{$\begin{array}{l}\mathbf{F} \\
.015\end{array}$} & \multirow{2}{*}{$\begin{array}{l}\text { Sig. } \\
.902^{\mathrm{a}}\end{array}$} \\
\hline 1 & Regression & & & & & \\
\hline & Residual & 98.223 & 98 & 1.002 & & \\
\hline & Total & 98.238 & 99 & & & \\
\hline
\end{tabular}

a. Predictors: (Constant), distributive justice

b. Dependent Variable: turnover intentions

Hypothesis 6 The simple linear regression analysis table suggests that hypothesis is not supported because the relationship between distributive justice and turnover intentions is highly insignificant. The level of significance is almost zero $\mathrm{F}(.015)=.01, \mathrm{p}<0.05)$ with an R2 of .000) explained by distributive justice. The value of significance is .902 which is insignificant at $95 \%$ significance level. The multiple regression analysis shows the overall significance or insignificance of all the three variables collectively with turnover intentions.

Table 9: Multiple regression analysis of justice and turnover summary

\begin{tabular}{lllll}
$\begin{array}{l}\text { Mode } \mathbf{R} \\
\text { I }\end{array}$ & \multicolumn{2}{c}{ R Square } & $\begin{array}{l}\text { Adjusted } \\
\text { Square }\end{array}$ & $\begin{array}{c}\text { R Std. Error of the } \\
\text { Estimate }\end{array}$ \\
\hline 1 & .255 & .065 & .036 & .97823 \\
\hline
\end{tabular}

a. Predictors: (Constant), distributive justice , intractional justice , procedural justice

Table 10: Multiple regression analysis of three dimensions of justice and turnover

\begin{tabular}{lllll}
\hline Model & Sum of Squares & Df & Mean Square \\
\hline 1 & Regression & 6.373 & 3 & 2.124 \\
Residual & 91.865 & 96 & .957 \\
Total & 98.238 & 99 &
\end{tabular}

a. Predictors: (Constant), distributive justice , interactional justice, procedural justice

b. Dependent Variable: turnover intentions

The multiple regression analysis tables revealed that the three dimensions of organizational justice (procedural, interactional and distributive justice) together are insignificant with turnover intentions. The level of significance is too low F $(2.220)=2.22, p<0.05)$ with an R2 of .056) means only 3\% turnover intentions explained by the all the dimensions of organizational justice collectively. The value of significance is .091 which is insignificant at $95 \%$ significance level.

Discussion and key findings
The rationale of this research study was to explore and test the relationship of the three dimensions of organizational justice (procedural, interactional and distributive justice) with organizational politics and employees turnover intentions. The findings supported the first part of the research model whereas the later part of the model wasn't supported by the results.

The procedural justice and organizational politics have a significantly negative relationship, whereas interactional justice and distributive justice are negatively related with organizational politics. Similar to the prior findings that politics and; procedural justice, distributive and interactional justice are negatively correlated (Andrews \& Kacmar, 2001; Byrne, 2005).

In nutshell the first part of the model is significant, the results exposed that the three dimensions of organizational justice predicting the politics to greater extent. The findings of this research have significant implications especially for managers to adopt fair treatment and procedures thus treat the employees in a fair manner. In turn the managers will be able to manage the negative effects of organizational politics. The findings related to the later part of the model were tentatively supportive; only one hypothesis is supported by the results. The findings of this research further revealed that procedural justice is the only variable which shows significance through the model.

Further results of my research show that there is significant negative relationship among procedural justice and turnover intentions. the prior research exposed that procedural justice can mitigate the negative effects of politics on turnover intentions means that procedural justice can play a significant role in this context. Further the prior study showed that procedural justice and turnover intentions have significant negative relationship with each other (Byrne, 2005).

Politics make the environment ambiguous which becomes less predictable. Likewise the long-term investment by employees turns to be risky when the due to politics the environment inside organization becomes unpredictable. Procedural justice brings stability and the element of control which reduces the level of unpredictability in the organization. The prior research studies proposed that fairness may possibly be the antithesis of organizational politics (Ferris \& Gilmore, 1995).

The findings of this research revealed that the relationship among interactional justice and turnover intentions is negative but it is considerably weak. Because the value of co-efficient of correlation (r) is almost close to zero which revealed that very weak negative relationship exists among the variables, which is contrary to the prior researches that support significant negative relationship between interactional justice and turnover intentions (Cohen-Charash \& Spector, 2001). The last findings of the research is that distributive justice has no relationship with turnover intentions the prior research measure only two dimensions of justice (procedural and interactional justice) with turnover. The hypothesis stated that there is significant negative relationship between distributive justice and turnover intentions but the results were not supportive.

The later part of the model is tests the relationship of the three dimensions of justice (procedural, interactional and distributive justice). The last part of the research model is collectively insignificant. The only one dimension of justice (procedural justice) is significant. The other two dimensions are not significant which make the overall model insignificant. There are a lot of reasons to answer the question why the results are not supporting later part of model.

The context where research has been conducted has so many different problems. The economy of the country is experiencing the hard phase of recession. So many economic factors like high level of unemployment and inflation exist in the region. The massive gap between demand and supply for the jobs in market for business graduates is one of vital factor. Furthermore the lack of job opportunities in the market affects the intention of employees to leave the job. On the other hand social and cultural factors also affect employee's intent to leave the organization. The worsening law and order situation has made the businesses environment very unpredictable for entrepreneurs-Thus the unpredictability and volatile 
job market makes it worth staying with the organization, rather than thinking or actually quitting.

\section{Limitations and future research}

The first limitation of the study was examined only three dimensions of justice while the recent dimension (informational justice) not included in the study. For further research the researcher should measure all the four dimensions of justice by including the informational justice. Future research is needed to measure the interaction of four dimensions with other key organizational outcomes. Bigger samples could improve generalizability.

\section{Conclusion}

In the recent times organizational politics is gaining more importance. Research studies proposed that Politics is necessary for the normal functions of any organization. But politics creates negative outcomes like conflicts, stress and intention to leave. In brief the research study provides a comprehensive insight that how organizational justice dimensions affects politics and key organizational outcome like turnover intentions. The findings of this research investigated the relationship of three dimensions of organizational justice with politics and turnover intentions.

Politics create uncertainty inside the organization atmosphere, which eventually becomes less predictable. Likewise the long-term investment by employees turns to be risky when the political environment inside organization becomes unpredictable. So managing organizational politics is a very sensitive and critical issue, therefore the study will facilitate human resource managers to cope up with organizational politics and their negative outcomes. To manage the negative outcomes of organizational politics the HR managers should realize the sensitivity of political environment inside organization. Organizational justice is considered to be a promising tool for coping with as well as mitigating these negative influences of organizational politics. The prior research studies proposed that fairness may possibly the antithesis of organizational politics.

Findings revealed that organizational justice brings stability and the element of control which reduces the level of unpredictability in the organization atmosphere. The findings of this research have significant implication especially for managers to adopt fairness in distribution of rewards, process and interaction with employees. Likewise the managers would be able to manage the negative effects of organizational politics. Finally it will create a better and competitive environment inside organization, which will bring efficiency and effectiveness in performance of employees. More research is necessary to help clarify the fairness and politics constructs and their relationship with one another.

\section{References}

Andrews, M. C., \& Kacmar, K. M. (2001). Discriminating among organizational politics, justice, and support. Journal of Organizational Behavior, 22(4), 347-366.

Byrne, Z. S. (2005). Fairness reduces the negative effects of organizational politics on turnover intentions, citizenship behavior and job performance. Journal of Business and Psychology, 20(2), 175-200.

Cropanzano, R., Howes, J. C., Grandey, A. A., \& Toth, P. (1997). The relationship of organizational politics and support to work behaviors, attitudes, and stress. Journal of Organizational Behavior, 18(2), 159-180.

Colquitt, J. A. (2001). On the dimensionality of organizational justice: A construct validity of a measure. Journal of Applied Psychology, 86, 386400

Ferris, G. R., \& Treadway, D. C. (1989). Politics in Qrganizations.

Ferris, G. R., Frink, D. D., Beehr, T. A., \& Gilmore, D. C. (1995). Political fairness and fair politics: The conceptual integration of divergent constructs.Organizational politics, justice, and support, 21-36.

Ferris, G. R., Brand, J. F., Brand, S., Rowland, K. M., Gilmore, D. C., King, T. R., \& Burton, C. A. (1993). Politics and control in organizations. Advances in group processes, 10, 83-111.

Folger, R., \& Konovsky, M. A. (1989). Effects of procedural and distributive justice on reactions to pay raise decisions. Academy of Management journal,32(1), 115-130.

Gandz, J., \& Murray, V. V. (1980). The experience of workplace politics.Academy of Management Journal, 23(2), 237-251.

Hom, P. W., Griffeth, R. W., \& Sellaro, C. L. (1984). The validity of Mobley's (1977) model of employee turnover. Organizational behavior and human performance, 34(2), 141-174.

Kacmar, K. M., \& Ferris, G. R. (1991). Perceptions of organizational politics scale (POPS): Development and construct validation. Educational and Psychological Measurement, 51(1), 193-205.

Kacmar, K. M., \& Baron, R. A. (1999). Organizational politics: The state of the field, links to related processes, and an agenda for future research.

Masterson, S. S., Lewis, K., Goldman, B. M., \& Taylor, M. S. (2000). Integrating justice and social exchange: The differing effects of fair procedures and treatment on work relationships. Academy of Management journal, 43(4), 738-748.

Nye, L. G., \& Witt, L. A. (1993). Dimensionality and construct validity of the perceptions of organizational politics scale (POPS). Educational and Psychological Measurement, 53(3), 821-829.

Pinto, J. K. (1997). Managers at Work: Make Politics Work for You. Research Technology Management 40(1), 9-10.

Randall, M. L., Cropanzano, R., Bormann, C. A., \& Birjulin, A. (1999). Organizational politics and organizational support as predictors of work attitudes, job performance, and organizational citizenship behavior. Journal of Organizational Behavior, 20(2), 159-174.

Tyler, T. R., \& Lind, E. A. (1992). A Relational Model of Authority in Groups.Advances in Experimental Social Psychology, 25, 115-191.

Tett, R. P., \& Meyer, J. P. (1993). Job satisfaction, organizational commitment, turnover intention, and turnover: path analyses based on meta-analytic findings.Personnel psychology, 46(2), 259-293. 